\section{Original} Article

Access this article online

Website:

www.ajobe.org

DOI:

10.4103/1817-7417.123081

Quick Response Code:

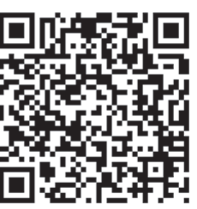

Address for correspondence: Ms. Elmé Vivier,

Human Sciences Research Council P.O. Box 1739, Wapadrand, Pretoria 0050, South Africa. E-mail: evivier@hsrc.ac.za

\title{
'A tough line to work through': Ethical ambiguities in a South African SME
}

\section{Elmé Vivier}

Human Sciences Research Council, Democracy, Governance and Service Delivery Programme, Pretoria , South Africa

\section{ABSTRACT}

The unique contexts and experiences of SMEs have recently been taken up as a gap within business ethics scholarship. In this exploratory paper, I aim to contribute to the knowledge of ethics within SMEs through an in-depth case study comprising interviews, site visits and document analysis of a South African SME. The paper examines the SMEs' three owners' perceptions of ethics and corporate social responsibility, as well as the ethical challenges arising from their employee relations. The case illuminates the deep uncertainties and contradictions that permeate the owners' values and practices and points to ethical decision-making as a process of reflection and moral imagination.

Key words: Corporate social responsibility, labour relations, moral imagination, small and medium enterprises, South Africa

\section{INTRODUCTION}

SMEs are exceptionally heterogeneous. They vary in company size, sector and management structure, as well as internal histories, dynamics and national contexts. Reviewing the literature on SMEs across country and regional contexts shows that, despite their diversity, there are notable similarities as well. Firstly, most SMEs are owner-managed ${ }^{i}$ and the personal values of the owner-manager orientate company culture and practices. Secondly, SMEs tend to exhibit a disjuncture between the theoretical construct and the actual practice of corporate social responsibility (CSR). Thus, whereas SMEs undertake informal social responsibility activities, they do not necessarily recognise the formal CSR discourse. Finally, employee relations and employee well-being are often one of the most critical factors for SME owners and even one of the key drivers of their social responsibility initiatives.

This paper aims to contribute to the literature through an in-depth examination of a South African SME in relation to these three aspects. It also addresses two additional gaps that have been identified by business ethics scholars: (i) The need for further study of SMEs within developing country contexts (Spence and Painter-Morland, 2010); and (ii) the need for empirical work to complement the wealth of theoretical scholarship (Spence and Rutherfoord, 2003). I begin with a review of the South African context, as well as the relevant literature on ethics in SMEs. I then discuss the methodological approach and the selected SME. This is followed by an exploration of the owner-managers' perceptions of ethics and CSR and their attitudes and experiences regarding employee relations. The case illuminates the ambiguities and contradictions that permeate the owner-managers' values and practices, as well as some of the influencing factors. I argue that the case points to ethical decision-making as a process of reflection and the significance of moral imagination, both in business practice and in the study of ethics in SMEs. I conclude with a consideration of the implications of the study for further research on ethics within SMEs.

\section{THE SOUTH AFRICAN CONTEXT}

South Africa is an ethnically, culturally and linguistically diverse society. Although nearly 20 years into its democracy and despite vast improvements in the extension of infrastructure and basic services to poor and marginalised communities, socio-economic and spatial inequalities remain (National Planning Commission, hereafter referred to as NPC, 2011:3). The SME sector is routinely hailed as an indispensable ingredient for 
addressing these challenges, vital for economic growth and sustainable development (Booysen, 2007:9; Fatoki and Chiliya, 2012:13; NPC, 2011:117). This is not only true for South Africa, but for much of the developing world, where unemployment, corruption and poverty persist (Spence and Painter-Morland, 2010:1). SMEs in developing countries thus face challenges to an extent that most SMEs in developed countries do not, such as lack of government support, burdensome regulation and heavy responsibility for job creation, coupled with lack of skills and infrastructure, the absence of safety nets and representative bodies (Tsoabisi, 2012:45; Kloppers and Kloppers, 2006:18; Spence and Painter-Morland, 2010:1-2).

In South Africa, SMEs account for nearly $91 \%$ of formal business entities and $61 \%$ of employment (Mahembe, 2011:7). It is also estimated that SMEs provided $90 \%$ of the jobs created between 1998 and 2005 (NPC, 2011:117). This prominent role of SMEs has been recognised in the National Development Plan, which sets out the long-term vision for the country (ibid.). While SMEs have featured in many such government plans (e.g. RDP, GEAR, ASGISA, New Growth Path), in reality, the SME sector continues to confront a difficult economic and labour environment, including policies that favour large corporations, financial constraints and burdensome labour legislation (Jeppesen, 2012; NPC, 2011; SBP, 2011). Furthermore, South African SMEs must also negotiate the legacies of apartheid, notably high levels of inequality and skewed ownership and control (NPC, 2011:118), as well as the oversupply of a largely unskilled, under-utilised and alienated labour force (Horwitz, Nkomo and Rajah, 2004:4). One of the most pressing challenges in South Africa, according to Robinson, in his $\mathrm{PhD}$ dissertation, A phenomenological study of how South African entrepreneurs experience and deal with ethical dilemmas (2002:201), "is to overcome the legacies of apartheid, which includes fostering an acceptable business ethic, containing crime and forging reconciliation between ethnic groups."

Law reform and affirmative action measures established since the transition to democracy aim to protect and uplift the disempowered, as well as to address some of these more 'intangible' and even ethical challenges. These law reforms include, amongst others, the Labour Relations Act of 1995, the Basic Conditions of Employment Act of 1997, the Employment Equity Act of 1999, the Skills Development Act of 1998 and the Broad-Based Black Economic Empowerment Act of 2003. Together, these aim "to achieve greater social justice and equality and to redress past unfair discrimination and unearned privilege" (Booysen, 2007:8). Even so, transformation has been slow, with top management across all sectors and company types in South Africa still held predominantly by white males (Department of Labour, 2013:38).
According to Chauke (2003:81-3), the new legislation also sought to address the intangible legacies of apartheid by forcing "an ideological shift" on organisations; that is, to "change the mind of the owners and managers" and thus "transform business cultures and identities." It aimed to democratise or 'South Africanise' the workplace so that it would reflect and embrace the diversity of South African society (ibid.). However, Booysen (2007) argues that the polarisation of social identities continues to manifest in the South African workplace (although this may be true for any workplace in any setting). It is beyond the scope of this paper to delve further into these issues, but it is necessary to acknowledge the complex dynamics of South Africa, especially insofar as owner values and employee relations are integral in the operations of SMEs (as is discussed in the next section).

\section{STUDIES ON SMES}

\section{Values and relationships: The informal nature of SMEs}

Most SMEs are owner-managed and the owners are directly involved in the day-to-day activities of the company, often undertaking multiple roles and functions. Rather than implementing a set of policies, codes and protocols, these owner-managers operate their companies primarily through informal practices and relations (Arruda, 2010:40, on Latin America; MacMahon, 1996:71; Murillo and Lozano, 2006:228; Spence and Perrini, 2010:43, on Italy). It is noteworthy, however, that, although SMEs are predominantly informal, degrees of formalisation may differ widely across companies. According to a longitudinal survey of German SMEs, for instance, companies tend towards greater formalisation of their management systems as they become larger, with micro enterprises remaining largely informal (Bürgi, 2010:161).

The direct involvement of the owner and the informal nature thereof means the values of the owner-manager often constitute the fundamental determinant of company ethics and practices. This has been confirmed for SMEs across country and regional contexts (for Europe see Murillo and Lozano (2006:229); Spence and Rutherfoord (2003:1-2); Klein and Vorbohle (2010:216); for Australia and New Zealand see Collins, Dickie and Weber (2010:52); for India see Srinivasan (2010:59); for South Africa see Viviers and Venter, 2008; Fatoki, (2012)). Following their study on fraud in SMEs in South Africa, for example, Viviers and Venter (2008:62) maintain that SME owner-managers must "set the ethical tone and commitment at the top, as employees' attitudes and behaviour towards fraud are more strongly influenced by management's actions than by the policies and procedures, which they lay down to combat it."

Similarly, across SMEs in Ireland, MacMahon (1996:71) found that even though "almost all companies had 
disciplinary procedures in place, all owner-managers felt that too rigid of an application of rules would alienate employees." Moving beyond the internal dynamics of the company, Srinivasan (2010:59) found that the informal nature of Indian SMEs confirms that "stringent governance norms that apply to large corporations may not be relevant [or] enforceable for SMEs, thus opening a space for owners to determine the company's ethical orientation and practices." Finally, Arruda (2010:70) situates Latin American SMEs' "flexible culture" within the challenging economic and regulatory context and describes their common philosophy as: "always find a way, no matter what and how you do it."

The predominance of informal practices suggests that relationships and connections between individuals are at the core of the SME environment. Spence and Rutherfoord (2003:2), for instance, emphasise social relationships in considering the ethics of small firms. This is taken up further by Perrini (2006:308; see also Painter-Morland and Dobie, 2009:14), who argues that research on SMEs should focus on social capital, that is, "on the existence of social networks and the norms of reciprocity and trustworthiness that arise from them." SMEs tend to operate locally and the owners often have direct, personal relationships with all stakeholders (Schlierer et al., 2012:40). Such close relationships generate trust, cooperation and reciprocity and enhance business sustainability (Murillo and Lozano, 2006:229; Perrini, 2006:312). Von Weltzien Hoivik and Melé (2009:558) speak of an "ethics of care" that focuses on relations of trust, shared consideration and mutual responsiveness, which gives space for individual feelings and values, even in business interactions.

Looking at South African SMEs, Fatoki (2012) explores the manner in which the personal values of owners influence stakeholder relations and argues that ethical values could have a positive impact on the availability of trade credit. Painter-Morland and Dobie (2009:14), in their exploratory study of sub-Saharan SMEs, furthermore acknowledge that at the core of such relationships are "complex negotiations and trade-offs between actors." For SMEs in particular, such trade-offs or motivating factors cannot be easily compartmentalised as either economic or social (ibid.). Rather, SMEs portray an integrated sense and negotiation of different interests, benefits and activities. This is especially clear in the literature on CSR within SMEs.

\section{Corporate social responsibility}

The second point of comparison is with regard to the concept and practice of CSR. There is growing consensus that CSR is not the most relevant or useful terminology for understanding ethics within SMEs (Perrini, 2006; Spence and Painter-Morland, 2010). Still, many studies on SMEs are framed around the notion of CSR, although some argue for simplified terminology such as 'social responsibility' (Spence and Perrini, 2009) or 'responsible competitiveness' (Murillo and Lozano, 2006). There is also no single, accepted definition of CSR (Kloppers and Kloppers, 2006:4; Perrini, 2006:306). Some emphasise its voluntary nature, others its transcendence of financial interests and legal requirements, its social or environmental impact, or its links to different stakeholders (Spence and Perrini, 2010:36).

It is often the informal character of SMEs that creates the disjuncture between CSR theory and practice. In their study of Catalan SMEs, Murillo and Lozano (2006:228) found that SMEs are uncomfortable with the concept of CSR, seeing it as "linked to actions that are beyond their reach or linked to large companies' concerns with their image" (2006:232). Spence and Painter-Morland (2010:3) concur, claiming that "SMEs find business ethics terminology frustratingly opaque." Schlierer et al. (2012:49) reported similar results across European SMEs with regard to the term 'stakeholder management'. Furthermore, Klein and Verbohle's (2010:219) empirical examination of German SMEs also found that, whereas small firms are aware of their social responsibilities towards society, they also understand that their contribution relies on their being economically healthy, especially since their major contribution is the provision of employment.

Interestingly, some of the research on South African SMEs reported positive support for CSR (see, for example, Viviers and Venter, 2008). Other studies suggest that CSR improves SME competitiveness insofar as it impacts on employee satisfaction, business reputation and customer loyalty (Jeppesen et al., 2012:124; Seeletse and Ladzani, 2012:3294). Fatoki and Chiliya (2012:19), in comparing local and immigrant SME owners' attitudes towards business ethics and CSR, similarly concluded that most owners are positive about business ethics and CSR and that they tend to believe that "improving the community's quality of life will also improve the long-run profitability of SMEs." However, they also found that "SMEs recognise that competitive pressures can impact on sound ethical decisions" (ibid.).

Regardless of whether SME owner-managers acknowledge or disregard the formal construct of CSR, evidence shows that SMEs across country and regional contexts undertake social responsibility activities. These practices are often "set within the daily discourse of the company's habitual business practices" (Murillo and Lozano, 2006:238), indicating that SMEs' CSR activities are not additional to, but enmeshed in general business practice. They are informal and unsystematic, do not comprise a structured CSR vision or strategy, are driven by internal management imperatives and often have low visibility (Klein and Vorbohle, 2010:223; Mandl and Dorr, 2007:1; Santos, 2010:187; Spence and Perrini, 2010: 43). 
These characteristics correspond with those reported for many SMEs across sub-Saharan Africa who "respond to the immediate concerns of their families and communities without formalising it as 'CSR projects' or framing it in these terms" (Painter-Morland and Dobie, 2009:13). However, implementation of CSR across Africa is often challenged by, amongst others, limited financial resources, poor management skills, weak governance, weak institutions, poor infrastructure, low productivity and insufficient profits (Turyakire, Venter and Smith, 2012:110). Still, in a study of Corporate Social and Environmental Responsibility (CSER) in SMEs in South Africa, Jeppesen, Kothuis and Ngoc Tran (2012:11-12) identified widespread informal CSER practices across the garment and textiles, agro-processing and tourism industries. These include giving employees loans or special leave, making donations to the community or charity, giving scholarships for workers' children and sponsoring sports clubs or sporting events (ibid.: $11 ; 28$ ). As these examples of informal CSR reveal, SMEs' social responsibility initiatives are often directed towards employees and employees often constitute the key stakeholder for SMEs, which is the focus of the next section.

\section{Employee relations and employee well-being}

The third similarity across SMEs is that employees are often the primary stakeholders for SME owner-managers (Klein and Vorbohle, 2010:222; Spence and Perrini, 2010:39). According to a South African SME owner-manager, "the people who make (the company) are the employees and thus the company believes it should be responsible for their health and well-being" (Seeletse and Ladzani, 2012:3291). Some scholars even argue that employee satisfaction is "paramount... to the success or failure of any business" (Mandl and Dorr, 2007:50; Turyakire et al., 2010:15). Most SMEs also see job creation as their primary contribution to society (Painter-Morland and Dobie, 2009; Spence and Perrini, 2010:38).

As noted in the previous section, SMEs' social responsibility practices are often directed towards employee well-being (see Klein and Vorbohle, 2010:218 on Germany; Mandl and Dorr, 2007 on the EU; Santos, 2010:183 on Portugal; Srinivasan, 2010:59 on India). Indeed, "the key motivation for socially responsible practices. is the concern for the employees' health and welfare" (Murillo and Lozano, 2006:229). This reiterates the importance of social relations for SMEs. According to Klein and Vorbohle (2010:223), owners tend to manage their business with a high degree of empathy, where employees are considered part of the family and their well-being coincides with that of the owners. This further reflects the fact that SME owners are often directly involved in the business operations. With regard to South African SMEs, Jeppesen et al. (2012:124) similarly found that social responsibility initiatives are primarily driven by their concern with human resource factors rather than business competitiveness.
Given the significance of employee relations, it is no surprise that many SMEs report labour relations as one of their top challenges. MacMahon's (1996:79) study of employee relations in Irish SMEs, for example, emphasises that SMEs' internal dynamics are highly susceptible to external factors such as tax structures and the product market situation. Arruda (2010:76) further picks up on the constraining impact of labour legislation in Brazil, which benefits the worker whenever there is a labour conflict. Although necessary to protect the rights of workers, most Brazilian SMEs perceive this as excessively protective and a burden on entrepreneurs (ibid.). Arruda (2010:73) also noted a common "fear of hiring" across these SMEs, due to the unreasonably stringent regulation that prevents owner-managers from easily dismissing workers.

Painter-Morland and Dobie (2009:9) similarly found labour issues to be prominent among SMEs in sub-Saharan Africa with regard to both perceptions of ethics and ethical problems. In terms of the latter, these dealt with issues of fair wages, treatment of staff and working conditions. Furthermore, they argue that employees in SMEs "are often the most disempowered part in terms of having a voice against the unfair treatment they receive," whilst SMEs often view employees as dispensable and replaceable (especially due to high rates of available labour) (2009:11). This appears to be contrary to Arruda's findings and may reflect differences between more and less regulated environments and their impact on employee voice. However, according to the SME Growth Index Report (SBE, 2011:21-3), many South African SMEs agree that inflexible labour legislation makes it "overly difficult and costly to get rid of under-performing or unsatisfactory staff" and essentially hinders business growth. Thus, a similar perception of legislation as overly protective of employees also appears in the South African context (see also NPC, 2011:118).

As the literature indicates, SMEs' opportunities for and challenges in practising good business ethics are embedded in the dynamics of informal practices and social relations (notwithstanding the impact of various formal, institutional and other external factors). It becomes pertinent, then, to examine how SMEs perceive and manage ethics and ethical challenges within this context.

\section{METHODOLOGY}

\section{Case study selection and research instrument}

This paper examines an SME in the Gauteng Province in South Africa. Although a single case study has limitations, especially given the diversity of SMEs, the case reveals the complex dynamics confronting South African SMEs. Moreover, such an exploratory micro-study provides an opportunity for insight into the meanings of things for ordinary people and has the potential to illuminate the tensions and contradictions underpinning people's beliefs and actions. 
The research process comprised a series of individual, face-to-face and open-ended interviews with the company owners, as well as site visits and analysis of relevant company documents. Interviewees were assured of confidentiality and anonymity; therefore, no names or identifying information of the individuals or the business are included in this paper. The company was selected based on my access to the three owner-managers, which allowed in-depth discussion and return consultations. The company has neither been recognised for exemplary social responsibility initiatives, nor is it the leader in its industry. However, I do not view these as limitations, but rather as factors signalling its potential relevance to the average South African SME. One of the limitations to this study, however, is the lack of employee voices.

The interview questionnaire drew and built upon the questionnaire fielded by Painter-Morland and Dobie (2009). My revised questionnaire looked at three key issues: (i) How SME owner-managers understand ethics within the SME environment and their perceptions of and practices related to CSR; (ii) the various internal and external causal factors of ethical/unethical business practices; and (iii) the dynamics of their internal labour relations, including relevant ethical issues, decisions and factors embedded within this relationship.

\section{Company profile}

The selected company operates within the furniture manufacturing industry. Founded in 1998, it started with two partners, in a garage. Today, there are three partners (owner-managers) and 50 employees. It is registered as a closed corporation and classifies as a small enterprise as per the National Small Business Act (in manufacturing, any business with 50 or fewer employees) (RSA, 1996). A total of $35 \%$ of staff is white, $65 \%$ is black African and $10 \%$ is female. At the time of the study, none of the employees were part of a union. Most of its business is local (within the Gauteng province) and national. The company is bound by the conditions of employment set out by the Furniture Bargaining Council, the Labour Relations Act and the Basic Conditions of Employment Act. These include all terms of employment: Work hours and overtime, leave days, dismissals, absenteeism, wage schedules and increases, safety measures, trade union relations, etc., According to a report by the Department of Trade and Industry (2008:1), although the furniture industry represents a small portion of the manufacturing sector, it is "one of the most labour-intensive industries with a potential to contribute to the reduction of unemployment."

\section{AT THE COALFACE: CASE STUDY FINDINGS}

Taking the previously mentioned themes as a starting point, the results of the study are presented, beginning with the way ethics is understood by the owners of the company, their perceptions of CSR and their experiences with regard to employee relations. What becomes evident is how the owners' beliefs and actions with regard to ethics are fraught with tensions and ambiguities.

\section{Perceptions of ethics: Owner values, relations and} informal practices

When asked how they understand the concept of ethics, the three owners' responses evoked notions of honesty and integrity. Ethics was defined as "an internal sense of what is right and wrong," where what is right means "delivering on your word and delivering on your promises." Although they had some difficulty at first in formulating their views on ethics, all three acknowledged the relevance of ethics within their business. 'Delivering on your word' easily translated into a notion of ethical business practice, defined as "providing a service and a product at a cost that a client agrees upon, [and] what he gets and what he expects matches up."

The owners also admitted that they "bend" their ethics "left and right": "You make promises to get the work and you hope you can deliver it sometimes, because you can't say no to the work." Whilst the pressure for work compels them to make unrealistic commitments, they also negotiate this through a further commitment to somehow get it right, at whatever cost (similar to Latin American SMEs, as noted by Arruda, 2010). For one owner, one of the most important commitments was to see each job through, no matter what it takes: "Even if you don't deliver on time, you never walk away."

Although the owners were generally positive about ethics, they also expressed a degree of uncertainty. One of them, for instance, struggled to give a clear view of what is right or wrong. He believed practising good business ethics would "come down to just thinking about the decisions you make that affect other people; to try and think about it in an ethical way; to not just try and think about it in a business way, [that is], about your profit." Thus, ethics is not simply about knowing and doing 'the right thing,' but about a process of reflection whereby one considers other interests, as well as the interests of others. Together, these articulations of ethics - keeping one's promises and reflecting on one's actions - point toward the relational basis of the SME environment. It is also across their various relations that these owners confront this uncertainty, as summed up in the following quote:

All that business is about is money... what's the right thing to pay people? What's the right price to charge your customers? What's a fair profit margin? What's fair of your customers to expect of you? What's fair of your employees to expect of you? Once you've paid them, do you owe them more than just money?

It is clear from this quote that the complex issue of fairness is embedded in the very nature of business. Beneath each 
economic exchange is a complex network of relations of responsibility. Since the owners are also active managers, this ethical dynamic comes to the fore in their daily activities and decisions.

In terms of operations, the company abides by national and industry legislation and regulations. They acknowledged the benefit of these "because that keeps everyone in check." However, these do not preclude the owners from reflecting on the legitimacy and fairness of the laws and regulations. One interviewee, for example, argued that the minimum wage for their industry is completely unethical, as it is not a sufficient living wage. It is impossible, however, for the company to pay employees more and still remain competitive. Beyond these formal rules, the company functions largely in an informal way, with the owners making decisions on a case-by-case basis, either individually or together. They sometimes also include the relevant employees. One of the benefits of being a small company, one partner explained, is that any employee can directly approach any of the owners with a problem. However, this also means that, if the employers are too busy at a particular time, employees do not have any formal mechanism or process on which to rely.

The owners also decide when to comply with particular policies and regulations. Resorting to prescribed disciplinary procedures with employees, for example, seems to be more of a hindrance than facilitation, as these do not accommodate the complexities of their reality. Thus, always 'going by the book' is simply not feasible. The difficulty for the owners, however, is knowing when to resort to formal procedures and when not to. This challenge was seen as a question of fairness. To treat staff fairly would mean to apply the same rules, in the same way, all of the time, to everyone (e.g. either giving or not giving warnings for tardiness and absenteeism). However, if they had to apply these disciplinary measures all the time, there would be an unmanageable staff turnover. On the other hand, to treat staff fairly also means to consider each individual person and situation. This is precisely where, for the employers, 'doing what you're supposed to do and what you think is right' do not always coincide. There is therefore a sense that ethics is not simply following the rules. Rather, practising good business ethics means negotiating the ambiguities of what is right and wrong, as well as negotiating the tensions between one's internal sense of what is right and what the law may require.

\section{Ethics as distinct from CSR}

In contrast to the findings of other studies on South African SMEs, not a single owner in this study associated ethics with CSR. They were all, to an extent, aware of the term, but saw it as far removed from their business and responsibilities, although they did believe one could practise good business ethics without undertaking any formal CSR. Their responses indicated a narrow understanding of CSR - something comprising only formal activities undertaken in impoverished communities, in addition to normal business activities. Examples included cleaning rivers, painting schools and spending time with underprivileged children. They seemed to exclude any activities performed internally, such as benefits for employees or business strategies to minimise environmental impact. Furthermore, CSR was perceived as something applicable to large corporations whose activities may have a negative (social and/or environmental) impact and who are therefore responsible for alleviating those impacts, because they have the capacity and resources to do so. In the case of their company, there was doubt as to whether the company could actually benefit from, or contribute to CSR. Arguments against CSR included lack of sufficient profit and the challenge of just running a business.

Their attitudes towards CSR further suggest that they doubt that a small company such as theirs could make a difference in South African society. As one put it, "we're just a company; we employ a couple of guys." Even though they viewed job creation as their main impact, they "don't help the poor to not be poor; they're still poor." Again, the issue of minimum wage was raised. Despite their rejection of CSR, the company does undertake informal practices regarded as social responsibility in the literature, such as giving loans or special leave to employees. They may therefore fall into what Zadek defines as non-strategic social responsibility, where a company is responsible "without even knowing it" (as cited in Santos, 2010:175). Since their CSR activities are aimed primarily at employees, I discuss these in more detail in the next section.

\section{Employee relations}

\section{Challenges and ambiguities}

Although the owners considered a number of stakeholders central to the company, it was within the employer-employee relationship that ethical practices and challenges were both the most prominent and the most problematic. As one owner put it, "for a small company, more of your employees are crucial employees... they all perform a crucial duty"; but this was also "the place where you will most be confronted with ethical issues." When asked what factors impact on their relationship with employees, the interviewees identified a range of issues, including language and skills gaps, employee misconduct (especially theft) and a constraining legal and regulatory environment. Again, their portrayals of these issues made clear that prescribed policies and procedures are not able to reconcile the ambiguities and even contradictions arising from their experiences. Yet, these tensions constantly emerge in the daily realities of the business:

People coming to you for loans. How do you treat that? People who don't come to work because of transport problems. How do you treat that? People who don't come to work because they need to take care of family members. People who steal. People who get sick, who then can't go to a doctor because 
they don't have money; who then, in turn, can't produce a doctor's note. Do you then pay them for the day or do you not? People who come late. How do you treat all of those things? Do you work strictly by the book on all of these things? Or do you take into account that person's situation? And at what point do you start to get abused by people?

As the last two questions from this interviewee reveal, there is a tension between, on the one hand, an ethic of care emerging from their cognisance of employees' personal challenges and on the other hand, a degree of doubt and distrust. Thus, they acknowledge South Africa's pervasive and conspicuous social, economic and spatial inequalities. Many employees, for example, travel long distances to work and are often the primary (or only) breadwinners in their family. One owner perceived the situation as follows:

You're working with minimum wage workers here; they live in the worst sort of areas known to man. You cannot fathom what they go through and what their living circumstances are and what they have to do just to get to work. You take so much for granted. this guy probably wakes up at four in the morning just to come to work, spends $3 \mathrm{~h}$ on a bus and then you kak (shit) him out for being late. that's just a tough line to work through.

There is also a limit to the trust and sympathy within this relationship. As will be discussed in the next section, the owners often feel that they are abused by employees, with constant theft being one of their main challenges. Another critical factor the owners believe impedes the relationship is language. Many of the employees speak minimal English or Afrikaans, which are the only languages spoken by the employers. This limits communication, as well as connection and mutual trust. Interestingly, race and culture were never mentioned as a point of conflict, although some of their perceptions do suggest racial and/or cultural differences (discussed briefly in the next section). Although it is difficult to speculate about these dynamics without the inclusion of employees' views, through an exploration of particular ethical dilemmas experienced by the owners, some of the complexities of this relation may be unpacked further.

\section{Employee loans}

In his in-depth study of entrepreneurs in South Africa, Robinson (2002:169) noted how "entrepreneurs deal with problems, opportunities, duality, complexity and inter-personal issues all day, every-day - their work-day is almost one continuous dilemma." In managing these dilemmas, the owners in this study reported unethical and even illegal practices. Yet, the most illuminating examples were with regard to subtle issues, such as the granting of loans.

Granting loans was one of the key practices discussed by the three owners with regard to ethics and employees. This corroborates findings by Jeppesen et al. (2012) that this is a common, informal CSR practice in South African SMEs. In the present company, one owner estimated that they have approximately 50 loans currently outstanding. These loans are relatively small, in their view (usually between R100 and R2 000) and are deducted without interest from employees' weekly salaries. Reasons for loans include: Transport costs to get to work, school clothes for employees' children, someone's house had burnt down and someone had been robbed.

While loans remain common within the company, the owners expressed various doubts about the need for and impact of this practice. On the one hand, "your heart melts and you have to do something." The challenge is that "it's not like someone that works on a factory floor can go to the bank to get a loan and if they do, the bank is probably going to come to you for the money in any case eventually. So I think we're their last, their only hope." Another, however, questioned the 'ethicality' of the practice. If it is intended to help employees, if it is driven by the employers' concern for the welfare and livelihood of their employees, then the question arises:

Are you really helping someone by giving him a loan and then deducting the money from him?.Maybe it's not right of you to do it, because you know for a fact that he can't pay it back and that you're just going to put him in a worse position than he is at the moment. Maybe, if you feel that he really needs that money, then you should give it to him.

These reflections from the owners indicate a sense of responsibility for employees, a concern for their employees being able to live 'a decent life,' and recognition that what they earn is hopelessly insufficient. However, there is also doubt as to the truth behind the reasons for which employees request loans. Again, there seems to be a limit to their trust, evident in their doubts as to whether, for instance, an employee did actually take his grandmother to hospital, or whether he was moonlighting instead. Hence, the decision is not always an easy or clear one. One of the partners was, in fact, adamantly against the practice of giving loans, describing it as "an African thing":

Why must you constantly borrow money? Because it's Africa. That's how people operate. They live in advance forever and ever and ever. We could just say no, but if you say no, you would not have them here tomorrow. Done. Guaranteed. That's how Africa works. You live in advance and you borrow. that's how factories work. It works like that everywhere in Africa.

Defining the practice as "an African thing" suggests that, for this owner, this internal company practice is determined by the cultural context in which they operate. It is therefore not a choice for the company and does not stem from either his own sense of social responsibility or his personal (or cultural) values. It is, however, noteworthy that, as another 
owner indicated, it is not only the black African employees who request loans from the company.

These different views show how one practice may be understood in terms of employee welfare, African culture and business sustainability. The example also reiterates the integrated nature of ethics within SMEs and illustrates how something easily identified as a social responsibility initiative is loaded with questions of fairness and justice. Whilst, in theory, this practice exemplifies good business ethics, it is not exempt from scrutiny, at least not for these individuals. As their views show, even between them, they are at odds over the ethicality of the practice. In the next section, I examine how the owners' uncertainties manifest in their attitudes and practices with regard to theft in the workplace.

\section{Theft, dismissals and the impact of the law}

One of the primary challenges the owners identified with regard to employees is theft. The issue is, however, made more difficult by stringent labour legislation, as noted previously. For one company, this legislation, in particular, prevents them from dismissing employees who are believed to be stealing. Apparently, theft (of tools from the factory or from sites) is a "massive issue." The employers claim to know, in some instances, who the perpetrators are, but are unable to provide sufficient proof as required by law. As one explained, "even if somebody tells you that they saw somebody stealing, that's not proof enough."

Although it is an ethical dilemma for them, when it comes to dismissals, the owners usually follow the law. In their view, the disciplinary process tends to favour the employee. Any procedurally unfair dismissal may result in the company being required to pay compensation to employees and the company is unable to afford these financial consequences. In such cases, they bring in their labour lawyer to assist with the process and to ensure that they do adhere to the legal requirements. However, the owners still doubt whether following the law in such a case is actually the right thing to do and they worry about its impact on their relations with other employees (e.g. that they would think the owners are subject to the dictates of the "strong" employees).

In their view then, their relationships with their employees are strained and constrained by legislation that does not allow them to 'weed out' problem individuals. This undermines the overall attitude and sense of trust on the part of the employers and perhaps on part of the other employees as well. Whereas the three owners expressed earnest concern for the well-being of their employees, they also conveyed their frustrations with the issue of theft and the challenge of dismissals. As one explained, being the 'nice' employer doesn't help; "it doesn't mean that your business is without theft." This example of how the employers deal with theft in the company and how it impacts on their attitudes regarding employee relations, once again reiterates the complexities of ethics in SMEs and how they must negotiate between what the law and policy require of them and what they believe is right.

\section{ETHICAL REFLECTION AND THE EXERCISE OF MORAL IMAGINATION}

The ethical awareness of the interviewees, alongside their constantly emerging uncertainties, brings to the fore the process of ethical decision-making. Although driven by their personal values and business interests, these owners admit that what is right is not always clear. Regardless of whether they should or should not give out loans, whether they should or should not follow proper procedures for dismissing employees, it matters that they grapple with the question of what they should do. Without any formal theoretical notions or terminologies, these individuals find themselves in the midst of that grey area that constitutes ethics in practice.

The reflection on and consideration of particular situations and consequences as expressed by these owners, I believe, may, to an extent, be construed as an exercise in moral imagination. In Moral imagination and management decision-making (1999:13), Patricia Werhane describes moral imagination as:

... a sense of the variety of possibilities and moral consequences of their decisions." It involves creative thinking about a particular person, situation, or dilemma, disengaging (as far as possible) from one's defined roles and conceptual schemes and evaluating the possibilities by asking what one ought to do (ibid.: 101-6). It specifically takes the particular phenomenon rather than general theoretical precepts as a starting point (ibid.: 92).

In this case study, the owners make decisions on a case-by-case basis, rather than through mere compliance with policy. Open discussions between the partners and sometimes with relevant employees, mean that a greater sense of different perspectives can be achieved. The partners themselves also often disagree on what they ought to do in particular cases. However, the extent of their discussions and thought processes is not entirely clear. One of the owners described his approach to resolving ethical conflicts as "winging it." They also admitted that, while their disagreements are good in principle, these also contribute to their uncertainties over what is right or wrong, thus complicating the decision-making process. Indeed, considering the widest range of perspectives, consequences and solutions could be debilitating.

The fuzziness of their decision-making processes may, to some degree, be seen as an indication of the limits of their exercising moral imagination. Consider 
also the fact that they failed to perceive some of their activities (such as giving loans) as practices of social responsibility (suggesting that their reflections are still limited to particular narratives or 'mental models'). The dearth of employees' voices (which may be assumed, given the noted language gap, although it cannot be emphatically asserted, given the lack thereof in this study) also curbs the ability of the owners to achieve a more balanced perspective. However, it is also the inaccessibility of all other views, the fact that one remains constrained by one's own subjective experience, which makes the process of ethical decision-making so complex. Thus, if an individual's values and sense of right and wrong are imbued with uncertainty, as in the case of these interviewees, then, I would argue, it essentially opens up the space for ethical decision-making. This is because they become aware of their lack of objectivity and of the ambiguities and tensions accompanying their various relationships. According to Werhane (1999:126), the exercise of moral imagination is not a process that seeks "infallible judgements" and at best, only provides "partial solutions."

This notion of ethical decision-making reverberates with Painter-Morland's claim in her seminal work business ethics as practice (2008:95) that "ethical decision-making in the workplace is typically conceived in deceptively simple terms - people and organisations think through ethical dilemmas, make decisions and act on them." However, closer consideration reveals "a far more complex set of dynamics at work in shaping moral behaviour" (ibid.: 96). For one, individuals are not just rational, objective subjects, "able to detach themselves from their private biases and emotions... [rather] the instrument most crucial to moral responsiveness. is the decision-maker's own humanity" (ibid.: 101). In this case study, the interviewees' reflections on their employee relations, on giving loans or applying formal policies, indicate that they do consider the impacts of such actions. Even if they may not always do the right thing, they continue to ask themselves the tough questions. Thus, regardless of their limitations, these employers often begin in a place of consideration, or return to a place of reflection.

\section{CONCLUSION}

Considering the evidence from the case study in relation to the literature on ethics in SMEs, the study confirmed that the owners' values largely determine company practices and policies (although there are exceptions). They draw their understandings of business ethics from their personal values, which is also a source of internal struggle. They often disagree with one another about what is right and they even believe some legislation is unethical. They operate in a combination of ad hoc decision-making and formal policy application and confront ethical questions in all their stakeholder relationships. Their uncertainties regarding ethics, however, suggest that having strong ethical values do not necessarily mean that what is right or wrong is clear and easy. Even when influenced by the owners' values, flexibility and tensions often characterise the SME environment.

With regard to CSR, the owners dismissed the relevance and occurrence of CSR in the company, yet they performed particular activities deemed as social responsibility (e.g. granting loans). It seems pertinent then to examine, firstly, the kinds of activities that SMEs identify as CSR, as well as activities or practices undertaken by SMEs that they may not classify as CSR, but which contribute to social well-being and sustainability. If SMEs are at the coalface of addressing poverty, unemployment and inequality, rethinking CSR means becoming more realistic about what SMEs are capable of doing and also perhaps becoming more positive about what SMEs are actually doing. We also, however, need to acknowledge the complex web in which actions are embedded, which might mean that actions that seem 'good' or 'beneficial' may not necessarily contribute to sustainable employment (evident in the expressed doubt about the impact of granting loans to employees).

The study further confirmed that the owners are very much driven by a concern for employees. However, they are constrained both internally and externally in ways that frustrate their decision-making and that complicate their relations with employees (e.g. policy and legislation, theft, language). What is also apparent is the complex dynamics of this relationship, which suggest that employer values, attitudes and actions cannot necessarily be easily characterised as positive or negative towards employees. What further complicates any analysis of this relationship is the lack of employee voices and more research needs to incorporate this critical perspective for better understanding of the SME environment and ethics within it.

Finally, the case illuminates how the reflective questioning of company practices by the owners constitutes, on some level, the nature of their ethics. Although the extent of their moral imagination may be limited, they often find themselves within that grey area where the question of what is right or wrong emerges. It is precisely here - in the realities of human experiences and relationships - that ethics becomes practice.

\section{FOOTNOTE}

Since most SME owners are also managers, the term 'owner-manager' is often used in the literature to refer to SME owners. In this paper, I use the two terms (owner-manager and owner) interchangeably. 


\section{REFERENCES}

Arruda, M. C. (2010). Latin America: Ethics and corporate social responsibility in Latin American small and medium sized enterprises: Challenging development (pp. 65-84). In Spence, L. J. and Painter-Morland, M. (Eds.). Ethics in small and medium sized enterprises: A global commentary. New York: Springer.

Booysen, L. (2007). Societal power shifts and changing social identities in South Africa: Workplace implications. South African Journal of Economic and Management Sciences, 10, 1-20.

Bürgi, J. (2010). A comprehensive model for SMEs: Measuring the dynamic interplay of morality, environment and management systems - Towards continuous improvement. In Spence, L. J. and Painter-Morland, M.(Eds.), Ethics in small and medium sized enterprises: A global commentary. (pp. 147-69). New York: Springer.

Chauke, P. (2003). The changing context: Organisational development in Southern Africa. In Moerdyk, A. and van Aardt, C. (Eds.) Organisational development: New methods and models for Southern Africa. (pp. 81-90). Glosderry, SA: New Africa Books.

Collins, E., Dickie, C., and Weber, P. (2010). A New Zealand and Australian overview of ethics and sustainability in SMEs (pp. 85-98). In Spence, L. J. and Painter-Morland, M. (Eds.). Ethics in small and medium sized enterprises: A global commentary. New York: Springer.

Department of Labour (DoL). (n.d.). Basic Conditions of Employment Act, summary. [Online]. Available from: http://www. labour.gov.za/DOL/legislation/acts/basic-conditions-of-employment/ basic-conditions-of-employment-act-and-amendments [Last accessed on 5 July 2013].

Department of Labour. (2013). Commission for Employment Equity Annual Report 2012-2013. [Online]. Available from: http://www.labour. gov.za. [Last accessed on 5 September 2013].

Department of Trade and Industry (DTI). (2008). Draft strategy for the development of the furniture industry. [Online]. Available from: http://www.pmg.org.za/policy-documents/2008/11/07/developmentfurniture-industry-draft-strategy. [Last accessed on 5 July 2013].

Fatoki, O. (2012). The impact of ethics on the availability of trade credit to new small and medium sized enterprises (SMEs) in South Africa. Journal of Social Science, 30, 21-9.

Fatoki, O. and Chiliya, W. (2012). An investigation into the attitudes toward business ethics and corporate social responsibility by local and immigrant SME owners in South Africa. Journal of Social Science, 32, 13-21.

Horwitz, K., Nkomo, S. M., and Rajah, M. (2004). HRM in South Africa (pp. 1-17). In Kamoche, K., Debrah, Y., Horwitz, F., and Muuka, G. N. (Eds.). Managing human resources in Africa. London: Routledge.

Jeppesen, S., Kothuis, B., and Ngoc Tran, A. (2012). Corporate social responsibility and competitiveness for SMEs in developing countries: South Africa and Vietnam: Agence Francaise de Developpement, Focales Series. Montligeon: France.

Klein, S. and Vorbohle, K. (2010). Corporate social responsibility and stakeholder relations - The perspective of German small and medium-sized enterprises (pp. 215-225). In Spence, L. J. and Painter-Morland, M. (Eds.). Ethics in small and medium sized enterprises: A global commentary. New York: Springer.

Kloppers H. J. and Kloppers E. M. (2006). A path out of poverty: A South African perspective on the role of SMEs in CSR. Paper presented at Corporate Responsibility Research Conference, 3-5 September 2006. Dublin, Ireland: ???.

MacMahon, J. (1996). Employee relations in small firms in Ireland: An exploratory study of small manufacturing firms. Employee Relations, 18, 66-80.

Mahembe, E. (2011). Literature review on small and medium enterprises' access to credit and support in South Africa. Underhill Corporate Solutions: Report for the National Credit Regulator.

Mandl, I. and Dorr, A. (2007). CSR and competitiveness: European SMEs' good practice. Consolidated European Report. European
Commission. [Online]. Available from: http://www.kmuforschung.ac.at/ de/Projekte/CSR/European\%20Report.pdf. [Last accessed on 5 July 2013]. Murillo, D. and Lozano, J. M. (2006). SMEs and CSR: An approach to CSR in their own words. Journal of Business Ethics, 67, 227-40.

National Planning Commission (NPC). (2011). National Development Plan: Vision for 2030. [Online]. Available from: http://www.npconline.co.za. [Last accessed on 8 November 2013].

Painter-Morland, M. (2008). Business ethics as practice. Cambridge: Cambridge University Press.

Painter-Morland, M. and Dobie, K. (2009). Ethics and sustainability within SMEs in sub-Saharan Africa: Enabling, constraining and contaminating relationships. African Journal of Business Ethics, 4, 7-19.

Perrini, F. (2006). SMEs and CSR theory: Evidence and implications from an Italian perspective. Journal of Business Ethics, 67, 305-16.

Republic of South Africa (RSA). (1996). National Small Business Act 102 of 1996. [Online]. Available from: http://www.info.gov.za/acts/1996/a102-96. pdf. [Last accessed on 5 August 2013].

Robinson, D. A. (2002). A phenomenological study of how South African entrepreneurs experiences and deal with ethical dilemmas. Dissertation submitted in fulfillment of the requirements for the degree of Doctor of Philosophy. ???: Rhodes University, Department of Management.

Santos, M. J. (2010). CSR and SMEs in Portugal: The strategy of obligation. In Spence, L. J. and Painter-Morland, M. (Eds.). Ethics in small and medium sized enterprises: A global commentary. (pp. 173-90). New York: Springer. SBP (Business Environment Specialists). (2011). Priming the soil: Small business in South Africa. Headline report of SBP's SME Growth Index. Johannesburg: SBP.

Schlierer, H., Werner, A., Signori, S., Garriga, E., von Weltzein Hoivik, H., Van Rossem, A., and Fassin, Y. (2012). How do European SME owner-managers make sense of 'stakeholder management'?: Insights from a cross-national study. Journal of Business Ethics, 109, 39-51.

Seeletse, S. M. and Ladzani, M. W. (2012). Thriving against the odds: A success story of a township building contractor. African Journal of Business Management, 6, 3288-95.

Spence, L. and Painter-Morland, M. (2010). Ethics in small and medium sized enterprises: A global commentary. New York: Springer.

Spence, L. and Perrini, F. (2010). Europe: Practice and politics: Ethics and social responsibility in SMEs in the European Union. In Spence, L. J. and Painter-Morland, M. (Eds.). Ethics in small and medium sized enterprises: A global commentary. (pp. 35-54). New York: Springer.

Spence, L. and Rutherfoord, R. (2003). Small business and empirical perspectives in business ethics: Editorial. Journal of Business Ethics, $47,1-5$

Srinivasan, V. (2010). CSR and ethics in MSMEs in India. In Spence, L. J. and Painter-Morland, M. (Eds.). Ethics in small and medium sized enterprises: A global commentary. (pp. 55-64). New York: Springer.

Tsoabisi, S. (2012). Supporting small medium and micro enterprises in South Africa. Mediterranean Journal of Social Sciences, 3 (12), 35-50.

Turyakire, P., Venter, E., and Smith, E. E. (2012). Corporate social responsibility for SMEs: A proposed hypothesised model. African Journal of Business Ethics, 6, 106-19.

von Weltzien Hoivik, H. and Mele, D. (2009). Can an SMME become a global corporate citizen? Evidence from a case study. Journal of Business Ethics, 88, 551-63.

Viviers, S. and Venter, D. (2008). Fraud: An SMME perspective. Southern African Journal of Entrepreneurship and Small Business Management NS, 1, 51-65.

Werhane, P. (1999). Moral imagination and management decision-making . Oxford: Oxford University.

How to cite this article: Vivier E. 'A tough line to work through': Ethical ambiguities in a South African SME. Afr J Bus Ethics 2013;7:26-36.

Source of Support: Nil, Conflict of Interest: None declared 


\section{AUTHOR}

Ms. Elmé Vivier is a researcher at the Human Sciences Research Council in the Democracy, Governance and Service Delivery programme. Before joining the HSRC, she taught philosophy and business ethics at the University of Pretoria, South Africa. She has a Master's degree in philosophy from the University of Pretoria. Her research interests are political theory, ethics, and governance, and citizen participation and public space. 
Reproduced with permission of the copyright owner. Further reproduction prohibited without permission. 